The final version of these remarks was published in the 2014 issue of the Proceedings of the $108^{\text {th }}$ Annual Meeting of the American Society of International Law.

\title{
Compliance of Canada's Utility Doctrine with International Minimum Standards of Patent Protection
}

\author{
Jerome H. Reichman \\ Bunyan S. Womble Professor of Law, Duke Law School.
}

Patents on chemicals, pharmaceuticals, gene sequences, and computer programs all raise similar issues about what functional effects are actually being claimed, described, and substantiated at the time of filing for patents. Because ground-breaking inventions are rare in these subject matter areas, would-be patentees are tempted to over-promise on utility in order to avoid challenges sounding in obviousness. ${ }^{1}$ The common policy at issue in all such cases is that patentees should not be allowed to "claim subject matter that goes beyond known or soundly predicted results on ... [the] date of filing.",

Lately, this problem has arisen in connection with certain pharmaceutical patents in Canada, largely because the pharmaceutical companies try to evergreen prior patents by claiming that a small selection of a number of previously patented compounds provides a "substantial advantage" that merits new patent protection. The "promise of the patent" doctrine in Canada seeks to ensure that firms do not obtain a legal monopoly on the basis of speculative claims about increased utility - especially claims about therapeutic efficacy - that were unsubstantiated at the time of filing. Under this test, some of Eli Lilly's patented pharmaceutical products have been invalidated retroactively, notably Strattera (a medicine to treat attention deficit hyperactivity (AHP)) and Zyprexa (a treatment for schizophrenia and related psychotic disorders). ${ }^{3}$

After losing an appeal against these decisions before Canada's Supreme Court, Eli Lilly filed a Notice of Arbitration against Canada under the North American Free Trade Agreement (NAFTA). ${ }^{4}$ The plaintiff claims that, because Canada's "promise of the patent" doctrine of utility violates international minimum standards of patent protection set out in both NAFTA and the WTO TRIPS Agreement of 1994, judicial invalidation of their patents on these grounds constituted a de facto expropriation inconsistent with the investment protection provisions of NAFTA.

The plaintiff's Notice of Arbitration in the Eli Lilly Case against the Union of Canada raises so many specious claims that to answer them all would take an entire afternoon. I will do the best I can in 15 minutes. Let me add, by way of disclaimer, that I was a consultant for Canada in the case that the Canadian Supreme Court dismissed last year.

To start with, the plaintiff claims that Canada's "promise" doctrine of utility is some new, ad hoc creation of its courts and that no other country applies such an approach. Richard Gold and Michael Short demonstrate instead that the promise of the patent has a long history in Canadian and British (pre-1977) patent law, and that similar tests are used in other Commonwealth countries, notably Australia and New Zealand.

Gold and Short also show that the United States applies a parallel approach by combining the doctrine of utility with the test of enablement, even though U.S. authorities are more tolerant of "metoo" drugs on the whole. Yet in certain other respects the U.S. utility doctrine of "specific and substantial utility" - adopted in 2005 - can invalidate more biotech patents than Canada, which does not impose a "substantial utility" test. Looking ahead, if Canada's old "promise of the patent test" allegedly violates

\footnotetext{
${ }^{1}$ E. Richard Gold \& Michael Short, The Promise of the Patent in Canada and Around the World, 30 CANADIAN INTELL. PROP. REV. 35 (2014).

${ }^{2}$ Id.

${ }^{3}$ See Eli Lilly of Canada v. Novopharm, [2013] 2 S.C.R. viii (Can.) (denying leave to appeal Eli Lilly of Canada, v. Novopharm [2012] F.C. 232).

${ }^{4}$ Eli Lilly v. Canada, Notice of Arbitration under NAFTA Chapter 11 at 1 (12 Sept. 2013), available at http://www.international.gc.ca/tradeagreements-accords-commerciaux/assets/pdfs/disp-diff/eli-01.pdf.
} 
international law as adopted in the 1990s, why did the tightened utility doctrine adopted by the United States in 2005 not similarly violate international minimum standards of patent protection?

Gold and Short also show that the European Patent Office (EPO) follows a parallel approach by combining its peculiar definition of invention as "the solving of a technical problem" with the EPO's own test of industrial applicability. In the end, the EPO applicant must show that it has achieved a technical effect or solution that amounts to an industrial application, which means that the product must demonstrate actual therapeutic efficacy beyond that of existing drugs to merit a legal monopoly. ${ }^{5}$ And, of course, as many of you know, India adopted a similar test in Article 3(d) of its patent law, in order to exclude pharmaceutical derivatives lacking enhanced therapeutic efficacy as not constituting "inventions." 6

If, as Gold and Short demonstrate, Canada's "promise of the patent" doctrine is neither new nor idiosyncratic, we must ask how it could possibly violate international laws applicable to patented inventions, particularly the TRIPS Agreement of 1994, which is said to mirror the relevant provisions in NAFTA. The plaintiff's most central claim is that Canada's approach violates the standard of utility set out in Article 27.1 of the TRIPS Agreement.

However, Article 27.1 of TRIPS does not even use the term "utility." It adopts the term "capable of industrial application" and in a footnote states that the term "capable of industrial application may be deemed by a Member to be synonymous with the term useful." ${ }^{, 7}$ But the text does not claim they are the same, and research shows they are, in fact different. States must use one or the other approach, but they are not the same. ${ }^{8}$

More importantly, neither TRIPS nor any other international agreement attempts to establish the substantive content of industrial applicability (utility), or, for that matter, of novelty and nonobviousness. The reason is that there is no consensus on how to apply these doctrines: state practices differ. What we find here are open-ended standards, not rules, whose content continues to evolve over time.

For example, we saw that, in 2005 the United States changed its utility criterion to "specific and substantial utility" in order to address overly broad claims in biotech patents. ' Similarly, the U.S. Supreme Court has repeatedly elevated the nonobvious standard since 1995, and it recently disqualified patents on some forms of isolated or purified DNA as patentable subject matter. ${ }^{10}$ The U.S. Supreme Court may invalidate more business method patents that rely on computerized applications for their novelty.

All these and other approaches remain valid precisely because there is no consensus on how to apply the novelty, nonobviousness, and utility standards of Article 27.1. To limit state flexibility under Article 27.1, we would need to negotiate and adopt uniform standards set out in the proposed Substantive Patent Law Treaty (SPLT) under consideration at the World Intellectual Property Organization (WIPO), which Rochelle Dreyfus and I criticized in 2007. ${ }^{11}$ But there is no consensus, and these negotiations broke down years ago.

In the absence of a consensus on the SPLT, there is no uniform or implicit standard of utility under TRIPS, other than the duty to implement treaty obligations in good faith. There are a lot of different

\footnotetext{
${ }^{5}$ Gold \& Short, supra note 1 , at 44.

${ }^{6}$ The Patent (Amendment) Act, 2005, No 15 sec. 3(d), Acts of Parliament 2005 (India).

${ }^{7}$ Agreement on Trade Related Aspects of Intellectual Property Rights, Apr. 15, 1994, Marrakesh Agreement Establishing the World Trade Organization, Annex 1C, art. 27, para. 1, 1869 U.N.T.S. 299; 33 I.L.M. 1197 (1994).

${ }^{8}$ Gold \& Short, supra note 1.

${ }^{9}$ See Manual Pat. Examining P. § 2107.01(A).

${ }^{10}$ See, e.g., Assoc. for Molecular Pathology v. Myriad Genetics, 133 S. Ct. 2107 (2013) (holding that a patent for synthetic composite DNA

(cDNA) isolated in the laboratory was invalid since the segments of DNA occurred in nature before they were isolated).

${ }^{11}$ Jerome H. Reichman \& Rochelle Cooper Dreyfus, Harmonization Without Consensus: Critical Reflections on

Drafting a Substantive Patent Law Treaty, 57 DUKE L.J. 85 (2007).
} 
state practices, which, as we have seen, continue to evolve. These practices are covered by the language of Article 1.1 of TRIPS, which expressly preserves states' sovereignty in this regard:

Members shall be free to determine the appropriate method of implementing the provisions of this Agreement within their own legal system and practice.

The space reserved for state sovereignty is further strengthened by Article 19.2 of the WTO's Understanding on the Settlement of Disputes (DSU), which declares that WTO panels and the Appellate Body in their findings and recommendations "cannot add to or diminish the rights and obligations provided for in the covered agreements." The WTO Appellate Body has chastised a panel for deviating from these norms in the India Mailbox Case of $1997 .{ }^{12}$

The reasoning is clear: in the trade context, there can be no unbargained-for trade concessions. Hence, the WTO Appellate Body says there can only be explicit obligations set out within the text of the TRIPS Agreement. National sovereignty concerning the implementation of patent eligibility standards is further buttressed by TRIPS Articles 7-8, viz:

\section{TRIPS (Part I) Article 7-Objectives}

The protection and enforcement of intellectual property rights should contribute to the promotion of technological innovation and to the transfer and dissemination of technological innovation and to the transfer and dissemination of technology, to the mutual advantage of producers and users of technological knowledge and in a manner conducive to social and economic welfare, and to a balance of rights and obligations.

TRIPS (Part I) Article 8-Principles

1. Members may, in formulating or amending their laws and regulations, adopt measures necessary to protect public health and nutrition, and to promote the public interest in sectors of vital importance to their socio-economic and technological development, provided that such measures are consistent with the provisions of this Agreement. ${ }^{13}$

More recently, the force of these safeguard provisions was further reinforced by the Doha Ministerial Declaration on TRIPS and Public Health, especially paragraph 4:

4. We agree that the TRIPS Agreement does not and should not prevent members from taking measures to protect public health. Accordingly, while reiterating our commitment to the TRIPS Agreement, we affirm that the Agreement can and should be interpreted and implemented in a manner supportive of WTO members' right to protect public health and, in particular, to promote access to medicines for all.

In this connection, we affirm the right of WTO members to use, to the full, the provisions of the TRIPS Agreement which provide flexibility for this purpose. ${ }^{14}$

These provisions show that TRIPS does not impose uniform law in any manner or shape. It established barely harmonized international minimum standards of protection that, in the absence of any Agreed Statement or official Acts, WTO members continue to apply differently in their respective efforts to adapt nineteenth-century patent law to twenty-first-century innovations. Nor does the application of Canada's utility doctrine discriminate against pharmaceuticals under Article 27.1. As Gold and Short

\footnotetext{
${ }^{12}$ WTO Appellate Body, India_-Patent Protection for Pharmaceutical and Agricultural Chemical Products (1997) WT/DS/50/AB/R, paras. 4748; See Jerome H. Reichman, Securing Compliance with the TRIPS Agreement After U.S. v. India, 4 J. INT'L ECON. L. 588 (1998). See further Reichman \& Dreyfus, supra note 11.

${ }^{13}$ See further Peter K. Yu, The Objectives and Principles of the TRIPS Agreement, 46 HousTON L. REV. 979 (2009).

${ }^{14}$ See World Trade Organization, Ministerial Declaration of 14 November 2001, WT/MIN(01)/DEC/1, 41 I.L.M. 746 (2006) (referred to as the

"Doha Rounds"), available at http://www.wto.org/english/thewto_e/minist_e/min01_e/mindecl_e.htm; See generally Frederick M. Abbott \&

Jerome H. Reichman, The Doha Round's Public Health Legacy Under the Amended TRIPS Provisions, 10 J. INT'L ECON. L. 921 (2007).
} 
show, that doctrine has always been applied to different subject matters in Canada and other countries for a long period of time. Besides, the nondiscrimination doctrine does not prevent reasonable differentiation when applying patent eligibility standards to different subject matters. ${ }^{15}$

Against this background, we are asked to believe that the investment protection provisions of NAFTA, drafted in the mid-1990s, somehow overruled or froze the intellectual property provisions otherwise embodied in TRIPS and NAFTA. This claim is preposterous on its face.

It would mean, among other things, that every decision by the U.S. Supreme Court or the Canadian Courts that changes the application of domestic eligibility standards is potentially ultra vires because those whose patents were adversely affected somehow have claims under the investment provisions of NAFTA. On what possible authority could the negotiators have agreed to freeze U.S. or Canadian intellectual property laws when the intellectual property provisions of the same treaties proclaim a totally different message, a message of reserved power of sovereignty over these same issues on which U.S. state practice has consistently relied?

Historically, investment protection laws bear on the conditions surrounding potential loss of specific investments by specific foreign investors in a host country. These laws may modify the general principles of customary public international law as applied to the expropriation of aliens' property as a quid pro quo for inducing particular aliens to invest in particular projects within the foreign host country.

Eli Lilly has made no specific investments in Canada pertaining to the drugs in question, nor has it negotiated any specific investment deals bearing on the facts of these cases. The only test of the patent standards applied by Canada or the United States under international law is whether or not they conform to TRIPS and the related international minimum standards embodied in the parallel intellectual property provisions of NAFTA, which they do. Implementing these standards cannot be treated as an illegal expropriation under any existing investment treaties, although certain pending investment treaties, if adopted as proposed, could unwisely move in this direction.

To claim that the investment provisions in NAFTA froze the international patent standards of TRIPS is to say that all the patent laws or judicial decisions in the United States, Canada, and elsewhere since the 1990s that have tightened patent eligibility standards to obtain better quality patents were illegal. That is tantamount to saying that the investment treaties were devised primarily to benefit patent trolls. Any attempt to freeze these intellectual property standards retroactively via a doctrine of estoppel under the investment treaties would arguably constitute an abuse of the investment provisions themselves - one that would not withstand judicial scrutiny.

The hard truth that Big Pharma cannot swallow is that U.S. patent law did not become global law under TRIPS, and that the United States cannot prescribe universal patent standards for the rest of the world any more than France could prescribe uniform patent law in 1883, when the Paris Convention was first adopted. Since TRIPS in 1994, there is, for the first time, a barely harmonized set of international minimum standards of eligibility. ${ }^{16}$ However, there is no duty to harmonize (despite scandalous " expert testimony' 'before the Canadian Supreme Court to the contrary).

Instead, under both TRIPS and NAFTA there is built-in flexibility to implement patent eligibility standards in each WTO member's domestic laws so as to advance states' own technological and economic development needs. ${ }^{17}$ No huffing and puffing about investment treaties will change these facts of life under international law as currently adopted.

\footnotetext{
${ }^{15}$ On this issue, see the Max Planck Declaration on Principles of International Patent Protection (Apr. 2014), at http://www.mpg.de/8132986/Patent-Declaration.pdf, signed by some fifty or more distinguished law professors from all major countries and continents.

${ }^{16}$ See Reichman \& Cooper Dreyfus, supra note 11.

${ }^{17}$ See, e.g., Jerome H. Reichman, Intellectual Property in the Twenty-First Century: Will the Developing Countries Lead or Follow?, 46 Houston L. REV. 1115 (2009).
} 